\title{
KEDUDUKAN SURAT WASIAT TERHADAP HARTA WARISAN YANG BELUM DIBAGIKAN KEPADA AHLI WARIS
}

\author{
Umar Haris Sanjaya \\ Fakultas Hukum Universitas Islam Indonesia \\ Email: umarharis@uii.ac.id
}

\begin{abstract}
Abstrak
Surat wasiat adalah kehendak terakhir yang dibuat pewasiat untuk dapat diterima dan dilaksanakan oleh penerima wasiat. Potensi menjadi tidak dilaksanakan bila wasiat yang dibuat obyeknya juga merupakan obyek waris. Hal itu terjadi bila ahli waris dan penerima wasiat tidak ada kesamaan mengenai harta peninggalan, sehingga kedudukan wasiat menjadi lemah. Penelitian ini mengambil rumusan masalah bagaimana kedudukan surat wasiat terhadap harta warisan yang belum dibagikan kepada ahli waris dan apakah surat wasiat harus dilaksanakan dahulu sebelum harta dibagikan kepada ahli waris. Hasil penelitian menemukan bahwa wasiat tidak mempunyai kedudukan yang absolut untuk dilaksanakan/eksekusi. Hal itu dapat terjadi bila pelaksanaan wasiat mendapatkan halangan sengketa dari ahli waris. Oleh karena itu wasiat yang dibuat sebagai kehendak terakhir dapat dikatakan belum tentu menjadi sebuah kehendak terakhir, karena itu memungkinkan dibatalkan. Pembatalan dilakukan bila para pihak yang sengketa mengajukan itu ke pengadilan, jadi kedudukan wasiat itu menjadi tidak absolut untuk dilaksanakan jika wasiat itu dibatalkan pengadilan.
\end{abstract}

Kata Kunci: Wasiat, Eksekusi, Absolut

\begin{abstract}
This research focused on the legal standing of testament toward inheritance property which devide yet. Testament recognized as a last will of person to be received by person who determined on it. Potentially, These will rise a dispute between testament receiver and the heir. It because of the heir would be bring it to the disputed if testament not desired. Thus, the testament would be not executed. This research using context of problems as how the legal standing of the testament toward inheritance property which devide yet and continue with is that testament should be execute absolutely toward inheritance property. Research result the testament has no absolutely legal standing to be execute toward inheritance property as long as rise the disputed. The dispute is related with the diclaimer from the heir toward testament substance. Thus, the testament is the last will of people do not perform well as the last will it because of the testament rejected probably. The rejection performed by court as well as the heir lawsuit.
\end{abstract}

Keywords: Testament, Execution, Absolute

\section{A. PENDAHULUAN}

\section{Latar Belakang}

Surat wasiat atau testament adalah suatu perbuatan hukum yang dilakukan sebelum seseorang itu meninggal. Wasiat biasa disebut dengan kehendak terakhir seseorang yang dimana kehendak itu akan diselenggarakan apabila ia telah 
meninggal dunia. Wasiat dapat dikatakan sebagai surat yang memuat ketetapan yang berisi kehendak-kehendak terakhir sebelum ia meninggal. ${ }^{1}$ Surat wasiat sendiri dibagi dalam 2 macam wasiat, yaitu wasiat yang dinamakan pengangkatan wasiat (erfsterlling) dimana berisi penunjukkan seseorang atau beberapa orang menjadi ahli waris, dan hibah wasiat (legaat). ${ }^{2}$

Surat wasiat yang dibuat seseorang harus ditunjukkan dengan bukti akta yang dapat dipertanggungjawabkan. Oleh karena itu pembuatan wasiat sepatutnya dibuktikan dengan adanya bukti tertulis, walaupun kita mengetahui bahwa Kompilasi Hukum Islam mengatur bahwa wasiat dapat dilakukan baik lisan maupun tulisan. ${ }^{3}$

Dijelaskan lebih lanjut bahwa surat wasiat yang dibuat haruslah berbentuk akta dan akta notaris. Artinya pembuatan surat wasiat memerlukan namannya pejabat umum untuk mengesahkan surat wasiat. Bilamana tidak dibuat dihadapan notaris, maka sipembuat wasiat yang menulis sendiir surat wasiatnya dapat menyerahkan surat wasiat itu kepada notaris setelah ditanda tangani. ${ }^{4}$

Surat wasiat harus dituangkan dalam bentuk akta wasiat, hal ini sesuai dengan ketentuan yang ada pada pasal 921 Kitab Undang-Undang Hukum Perdata yang menyatakan "untuk menentukan besarnya bagian mutlak dalam sesuatu warisan, hendaknya dilakukan terlebih dahulu suatu penjumlahan akan segala harta peninggalan yang ada di kala si yang menghibahkan atau mewariskan meninggal dunia. Kemudian ditambahkannyalah pada jumlah itu, jumlah dari barang-barang yang dihibahkan diwaktu si meninggal masih hidup, barang-barang mana masih harus ditinjau dalam keadaan tatkala hibah dilakukannya, namun mengenai harganya, menurut harga pada waktu si penghibah atau si yang mengwariskan meninggal dunia, akhirnya dihitunglah dari jumlah satu sama lain, setelah yang ini dikurangi dengan semua hutang si meninggal berapakah, dalam keseimbangan dengan kederajatan para ahli waris mutlak, besarnya bagian mutlak mereka, setelah mana bagian-bagian ini harus dikurangi dengan segala apa yang telah mereka terima dari si meninggal, pun sekiranya mereka dibebaskan dari wajib pemasukan".

\footnotetext{
J.Satrio, Hukum Waris, Bandung: Alumni, 1992, hlm. 180.

Ibid.

3 Yahya Harahap, Kedudukan, Kewenangan dan Acara Peradilan Agama, Jakarta: Sinar Grafika, 2003, hlm. 150.

4 Tamakiran, Asas-Asas Hukum Waris Menurut Tiga Sistem Hukum, Bandung: Pioner Jaya, 1992, hlm. 29.
} 
Penjelasan mengenai wasiat tidak hanya diatur pada Kitab Undang-Undang Hukum Perdata, secara praktek dimasyarakat wasiat sudah sering digunakan. Artinya dalam kebiasaan dimasyarakat hal semacam pelaksanaan wasiat sudah menjadi hal yang biasa, ini disebut sebagai amanat terakhir. ${ }^{5}$ Pelaksanaan dari amanat terakhir dipahami sebagai bentuk penetapan terhadap harta peninggalan yang nanti akan ditinggalkan kepada ahli waris. Pernyataan ini biasanya dilakukan dan dengan persetujuan dari ahli waris. ${ }^{6}$

Amanat terakhir ini dilakukan untuk membuat ketetapan yang sifatnya mengikat bagi mereka segenap ahli waris. Hal ini bertujuan untuk meminimalkan sengketa yang dimbul kelak ketika pewaris meninggal. Apa yang diuraikan pada amanat terakhir ini, yaitu seluruh harta, cara pembagian, dan menetapkan siapasiapa yang menerima beserta besaranya. ${ }^{7}$

Mengingat ini merupakan sebuah pernyataan kehendak dari seseorang yang membuat amanat terakhir, bisa dipastikan pembuatan dari amanat terakhir ini setiap waktu dapat berubah, ditarik kembali oleh ia yang membuatnya. ${ }^{8}$ Mengingat praktek dari amanat terakhir yang dilakukan sudah menjadi kebiasaaan di masyarakat, maka perlu dilihat apakah perbuatan itu juga bagian dari perbuatan hukum. Secara hukum pada ketentuan pasal 876 Kitab Undang-Undang Hukum Perdata dinyatakan bahwa suatu pengangkatan waris adalah sebuah wasiat, ${ }^{9}$ dengan mana si yang mewasiatkan, kepada seorang atau lebih memberikan harta yang akan ditinggalkannya apabila ia meninggal dunia baik seluruhnya maupun sebagian seperti misalnya setengahnya, sepertiganya.

Wasiat juga dikenal di dalam hukum islam, hal ini dikemukakan pada Kompilasi Hukum Islam (KHI) pasal 171 dan dipertegas pada pasal 195. KHI menyatakan bahwa wasiat adalah pemberian suatu benda dari pewaris kepada orang lain atau lembaga yang akan berlaku setelah pewaris meninggal dunia. Artinya wasiat merupakan bentuk tasaruf terhadap harta peninggalan yang akan berlaku setelah dilaksanakan setelah meninggalnya orang yang berwasiat. ${ }^{10}$

\footnotetext{
Iman Sudiyat, Hukum Adat, Sketsa Asas, Yogyakarta: Liberty, 1981, hlm. 13.

Ibid.

Ibid., hlm. 14.

82.

Oemarsalim, Dasar-Dasar Hukum Waris di Indonesia, Jakarta: Rineka Cipta, 1991, hlm.

9 Kitab Undang-Undang Hukum Perdata Pasal 876.

10 Satria Efendi M. Zein, Problematika Hukum Keluarga Islam Kontemporer, Jakarta: Prenada Media, 2004, hlm. 398.
} 
Lebih lanjut KHI menjelaskan bahwa untuk membuat wasiat dapat dilakukan secara lisan yang disertai dengan 2 orang saksi, atau tertulis di hadapan 2 orang saksi, atau dibuat dihadapan notaris. Hal yang terpenting lagi adalah wasiat yang yang dibuat hanya berlaku bila itu semua telah disetujui oleh ahli waris. ${ }^{11}$

Artinya wasiat merupakan perbuatan hukum yang pelaksanaannya diwadahi atas ketentuan hukum yang bersumber pada Kitab Undang-Undang Hukum Perdata, Kompilasi Hukum Islam, dan telah menjadi kebiasaan dimasyarakat atau dikenal dengan perbuatan hukum adat. ${ }^{12}$ Dijelaskan lebih lanjut bahwa wasiat dalam bahasa daerah masing-masing seperti dijawa dikenal welingan atau wekasan. ${ }^{13}$ welingan adalah berupa kemauan terakhir dari si peninggal warsan agar dapat segera menentukan bagaimana nanti harta kekayaannya dapat dibagikan kelak kepada anak-anaknya.

Perbuatan itu ditujukan dengan maksud :

1. Mewajibkan pada ahli warisnya membagi-bagi harta peninggalan dengan cara yang layak menurut anggapannya.

2. Mencegah perselisihan, keributan, dan cekcok dalam membagi harta peninggalannya di kemudian hari diantara para ahli waris.

3. Selain itu welingan ini menjadi alat yang mengikat bagi si peninggal wasiat terhadap barang harta warisan agar terikat di welingan yang dibuat.

4. Mewajibkan para ahli waris untuk menghormati penetapan pesan terakhir walaupun itu dapat menyimpang dari ketentuan hukum waris maupun hukum waris adat. ${ }^{14}$

5. Sebagai penyeimbang terhadap ketentuan hukum waris yang dipandang tidak adil atau tidak memuaskan si pewaris. ${ }^{15}$

Dari penjelasan diatas, dapat diketahui bahwa suatu wasiat atau welingan yang dibuat oleh masyarakat umum mempunyai kekuatan hukum bila itu dibuat baik secara lisan atau tertulis yang kemudian dibuat dihadapan notaris.

11 Rahmadi Usman, Hukum Kewarisan Islam, Bandung: Mandar Maju, 2009, hlm. 144145.

12 Tolib Setiady, Intisari Hukum Adat Indonesia (dalam kajian kepustakaan), Bandung: Alfabeta, 2013, hlm. 290.

13 Ibid.

14 Dominikus Rato, Hukum Perkawinan dan Waris Adat (sistem Kekerabatan, Bentuk Perkawinan, dan Pola Pewarisan Adat di Indonesia, Surabaya: Lasbang Yustisia, 2011, hlm. 213.

15 Mulyadi, Hukum Waris Tanpa Wasiat, Semarang: Badan Penerbit Universitas Diponegoro Semarang, 2008, hlm. 24. 
Ditambahkan dalam KHI bahwa wasiat harus dihadiri 2 orang saksi yang bersaksi dan disetujui oleh mereka para ahli waris. Jadi penulis meneliti disini untuk menguji kedudukan surat wasiat yang telah dibuat dan disetujui oleh mereka para ahli waris tetapi tidak dilaksanakan hingga si penerima wasiat itu meninggal hingga harta wasiat itu dianggap sebagai harta warisan.

Pada penelitian ini, penulis coba menguraikan kedudukan dari wasiat atau welingan yang dilakukan oleh bapak Notodiharjo (disebut Pak Noto) kepada mereka 10 anak-anaknya yaitu Benny anak pertama, Herwan anak kedua, Asiyah anak ketiga, Handoko anak keempat, Bambang anak kelima, Harmintiasih anak keenam, Gunarso anak ketujuh, Sri Rahayu anak kedelapan, Ery anak kesembilan, dan Edy anak kesepuluh.

Kasus hukum waris dan wasiat terjadi ketika anak pertama yaitu pak Benny selaku penerima wasiat terhadap harta bagiannya berupa tanah di Gedongkuning, Babadan, Banguntapan Bantul no. s.96/iv dengan luas 4735 Meter persegi tidak mendapatkan hak bagiannya sebagaimana tertera didalam surat wasiat. Istri dan anak keturunan dari Benny tidak bisa memiliki tanah tersebut, karena ketika Benny meninggal tanah tersebut masih atas nama Pak Noto. Hal ini yang kemudian dijadikan dasar oleh adik dari Benny yaitu 9 orang ahli waris pak Noto beserta janda dari Pak Noto untuk menggugat pembagian waris terhadap obyek tanah tersebut. Padahal tanah itu merupakan tanah yang diperuntukkan untuk Benny sesuai isi wasiat.

Wasiat yang dimaksud dibuat pada tanggal 30 Desember 1982 oleh bapak Noto yang dilakukan di Tempelsari, Caturtunggal, Depok, Sleman. Tujuan dari wasiat ini untuk membagi-bagikan harta kekayaan berupa tanah kepada anakanaknya. Dari hasil pembagian dinyatakan bahwa masing-masing anak telah mempunyai jatah bagiannya masing-masing.

Disamping pembuatan wasiat, pak Noto juga membuat surat persetujuan oleh para ahli waris yang dibuat pada tanggal dan tahun yang sama yaitu 30 Desember 1982 dimana mereka semua memberikan tanda tangan dan menyatakan jelas menyetujui bahwa obyek tanah yang dimaksud penulis telah dilintirkan kepada Benny. Tujuan dibuatnya surat persetujuan waris ini untuk memperjelas bahwa 
mereka para ahli waris Pak Noto setuju bahwa obyek tanah tersebut memang dilintirkan pada Benny. ${ }^{16}$

Surat wasiat yang dibuat pada tanggal 30 Desember 1982 itu kemudian diperjelas lagi pada surat wasiat dan kuasa yang dibuat oleh Pak Noto pada tanggal 16 Maret 1974. Isi dari surat wasiat dan kuasa itu adalah memberikan obyek tanah diatas untuk dimiliki turun-temurun, dikuasai/diserahkan kepada Benny selaku anak pertama. Pak Noto sendiri meninggal pada 16 Januari 1995.

Dalam tempo waktu pak Noto meninggal dunia tahun 1995 hingga Benny meninggal pada 13 Februari 2001, obyek tanah tersebut masih berstatus atas nama Pak Noto, artinya belum ada perubahan kepemilikan. Hal ini yang kemudian dijadikan dasar oleh mereka para ahli waris pak Noto yang menggugat para ahli waris Benny untuk dilakukan pembagian waris. Karena ahli waris pak noto menganggap bahwa tanah Benny itu adalah tanah dari Pak Noto.

Upaya hukum itu tertuang pada putusan No.09/Pdt.G/2004/PN.Btl yang memutuskan dan mengadili bahwa sesungguhnya upaya hukum yang dilakukan oleh ahli waris Pak Noto itu tidak dapat diterima oleh majelis hakim. Pada upaya banding Pengadilan Tinggi Daerah Istimewa Yogyakarta No. 12/Pdt/2005/PT.Y memberikan putusan yang berbeda, yaitu mengadili bahwa memperbaiki putusan No.09/Pdt.G/2004/PN.Btl yang redaksinya berubah menjadi menyatakan bahwa tanah obyek sengketa adalah harta peninggalan dari almarhum Pak Noto yang belum dibagi waris dan berhak mewaris terhadap obyek tanah tersebut. Pada tingkat kasasi, Mahkamah Agung menolak upaya kasasi melalui Putusan MA No. $2332 \mathrm{~K} / \mathrm{Pdt} / 2005$. Yang artinya MA memutuskan bahwa obyek tanah itu merupakan harta waris Pak Noto, bukan menjadi milik Benny.

Dari gambaran diatas, penulis ingin meneliti lebih lanjut tentang kedudukan surat wasiat terhadap harta warisan yang belum dibagikan dengan menilai bagaimana kedudukan surat wasiat terhadap harta warisan yang belum dibagikan kepada ahli waris.

16 Surat persetujuan waris yang dibuat telah diketahui dan mendapatkan pengesahan dari Kelurahan Kepada Desa Caturtunggal tertanggal 29 Januari 1999 dan dikuatkan oleh Camat Depok tertanggal 1 Februari 1999 yang isinya adalah Benny adalah penduduk desa setempat, dan Pak Noto adalah warga desa setempat. 


\section{Rumusan Masalah}

Berdasarkan latar belakang di atas, letak permasalahan yang ingin diteliti diuraikan dalam pertanyaan sebagai berikut. kedudukan surat wasiat terhadap harta warisan yang belum dibagikan kepada ahli waris dan surat wasiat harus dilaksanakan dahulu sebelum harta dibagikan kepada ahli waris.

\section{B. HASIL DAN PEMBAHASAN}

\section{Tinjauan tentang Wasiat}

Mengkaji tentang kajian terhadap wasiat tentunya tidak akan lepas dari kajian terhadap masalah kewarisan. ${ }^{17}$ Pada konteks ini, wasiat selalu dijadikan bagian yang tidak dapat dipisahkan dengan masalah waris. Karena pelaksanaan sebuah wasiat sendiri baru dapat dilakukan apabila seorang pewasiat itu telah meninggal dunia. Sejalan dengan meninggalnya pewasiat maka saat itu pula si pewasiat juga bersatus menjadi pewaris bagi para ahli warisnya.

Penambahan status seorang pewasiat yang telah meninggal dunia dengan menjadi pewaris inilah yang kemudian kadang pelaksanaan wasiat berpotensi tidak terlaksanakan. Tentunya hal ini disampaikan dengan tidak melanggar suatu hukum atau undang-undang. ${ }^{18}$ Hal itu disebabkan oleh beberapa hal yang halangannya karena pelaksanaan wasiat itu dihalangi oleh para ahli waris dari si pewasiat. Akibatnya pelaksanaan hukum wasiat yang sudah dibuat secara hukum dapat saja dihapus, dihentikan, atau dikurangi dari jumlah wasiat yang sudah ditentukan. Tentu hal ini dapat dilakukan melalui proses hukum yang berlaku.

Dari uraian singkat diatas, perlu dipahami bahwa sesungguhnya wasiat itu perlu adanya perlindungan hukum bagi para penerima wasiat. ${ }^{19} \mathrm{Hal}$ itu tentunya harus sesuai dengan pemahaman hukum terhadap wasiat.

Wasiat atau dibahasakan dengan testament diartikan dengan sebuah pernyataan dari seseorang tentang apa yang ia kehendaki setelah ia meninggal dunia. Kata pernyataan ini memberikan kesan hukum bahwa wasiat itu dilakukan oleh satu pihak (eenzijdig). Bila itu pernyataan suatu pihak, maka tentunya

17 Sajuti Thalib, Hukum Kewarisan Islam di Indonesia, Jakarta: Sinar Grafika, 2000, hlm. 104.

18 Sesuai pada pasal 872 Kitab Undang-Undang Hukum Perdata.

19 Abdul Manan, Aneka Masalah Hukum Perdata Islam di Indonesia, Jakarta: Prenada Media Group, 2006, hlm. 95. 
pernyataan tersebut dapat dicabut kapan saja oleh ia yang membuat pernyataan. ${ }^{20}$ Ada pula yang menyebut bahwa wasiat merupakan kehendak terakhir, yaitu kehendak yang baru akan terselenggara apabila pewasiat telah meninggal dunia. Kehendak ini dibuat dengan sebuat ketetapan berupa akta yang isi-isinya telah dikehendaki oleh yang membuatnya. ${ }^{21}$

Wasiat diatur pada pasal 875 yang isinya, ada pun yang dinamakan surat wasiat atau testamen ialah suatu akta yang memuat pernyataan seorang tentang apa yang dikehendakinya akan terjadi setelah ia meninggal dunia, dan yang olehnya dapat dicabut kembali lagi. Dari pengertian ini, maka wasiat itu dapat terjadi bila memiliki unsur $:^{22}$

1. Berupa akta, artinya wasiat itu berupa tulisan yang dibuat dengan akta otentik ataupun dibawah tangan;

2. Ada pernyataan kehendak, artinya kehendak itu adalah keinginan sepihak. Keinginan ini dapat menimbulkan akibat hukum sepihak;

3. Meninggal dunia, artinya wasiat ini baru berlaku apabila seseorang yang berwasiat itu telah meninggal; dan

4. Dapat dicabut kembali olehnya, artinya perbuatan hukum wasiat ini dapat tidak dilaksanakan bila isi wasiat itu dicabut oleh yang membuatnya.

Terhadap pembuatan wasiat itu pun memerlukan syarat-syarat yang jelas tertera didalam Kitab Undang-Undang Hukum Perdata. Syarat yang berlaku dalam wasiat adalah $:^{23}$

1. Ada orang yang berwasiat. Orang ini hendaklah orang yang sudah cakap dimata hukum; ${ }^{24}$

2. Ada orang yang menerima wasiat, artinya penerima wasiat pada saat ia ditetapkan dan hendak menerima dalam keadaan hidup; ${ }^{25}$

20 Idris Ramulyo, Perbandingan Pelaksanaan Kewarisan Islam Dengan Kewarisan Menurut Kitab Undang-Undang Hukum Perdata (BW), Jakarta: Sinar Grafika, 2003, hlm. 132.

21 J. Satrio, Hukum Waris, Bandung: Alumni, 1992, hlm. 180.

22 J. Satrio, Op.cit., hlm. 181-182.

23 Ali Afandi, Hukum Waris, Hukum Keluarga, dan Hukum Pembuktian Menurut Kitab Undang-Undang Hukum Perdata (BW), Jakarta: Rineka Cipta, 1997, hlm. 58.

24 Pasal 897 Kitab Undang-Undang Hukum Perdata mengatakan bahwa minimal 18 tahun untuk membuat wasiat.

${ }^{25}$ Pasal 898 Kitab Undang-Undang Hukum Perdata mengatakan bahwa seseirang itu harus telah ada. 
3. Ada harta wasiat, harta wasiat ini berupa benda yang pada saat diwasiatkan itu ada keberadaannya baik itu aktiva atau pasiva. Benda yang dimaksud dalam konteks ini adalah benda yang dapat dinilai dengan uang. Lebih detail hal yang diwasiatkan seperti hak eigondom, hak erfpacht, kreditor, debitor, ada juga hak yang timbul karena suatu hubungan kontraktual seperti hak pada perjanjian tenaga kerja, perkongsian, perseroan, ataupun firma. ${ }^{26}$

Dapat disimpulkan secara lebih detail lagi tentang harta wasiat, maka $:^{27}$

a. Dapat berupa benda bergerak ataupun benda tidak bergerak;

b. Dapat berupa hak, hak lain dari harta kekayaan, seperti hak membeli, hak menjual; dan

c. Dapat berupa hak, hak untuk menikmati, seperti menikmati rumah, saham, uang.

Secara substansi dalam memahami wasiat, Kitab Undang-Undang Hukum Perdata membagi 2 macam tentang isi wasiat. Hal itu kembali pada isi-isi yang dikehendaki oleh si pewasiat seperti :

1. Wasiat pengangkatan waris (erfsterlling)

Subekti menyampaikan bahwa, "salah satu cara seseorang untuk dapat mendapatkan warisan adalah dengan penunjukkan didalam surat wasiat (testament)". Hal ini ia katakan dengan sebutan ahli waris testamentair. ${ }^{28}$ Wasiat ini merupakan sebuah kehendak yang diinginkan seseorang sebelum ia meninggal. Kehendak itu berlaku setelah orang itu meninggal dan kehendak tersebut tidak boleh bertentangan dengan undang-undang. Oleh sebab itu dengan adanya erfsterlling ini, seseorang yang ditunjuk dalam wasiat ini maka mempunyai kedudukan seperti halnya ahli waris ab-intestato. ${ }^{29}$

Oleh karena itu isi dari sebuah pengangkatan waris adalah kehendak (erfslling), dimana hal kehendak itu berkaitan dengan harta warisan. Karena ahli waris dan penerima wasiat ini sama-sama memiliki kedudukan yang sama.

\footnotetext{
26 Pada konteks hubungan kontraktual, maka dapat berakhir bila ada kematian dari salah satu pihak.

27 G. Kartasapoetra, R.G. Kartasapoetra, Pembahasan Hukum Benda, Hipotek, dan Warisan, Jakarta: Bumi Aksara, 1994, hlm. 90-94.

28 Subekti, Pokok-pokok Hukum Perdata, Jakarta: Intermasa, 1994, hlm. 95.

29 Tamakiran, Asas-asas hukum waris menurut tiga sistem hukum, Bandung: Pioner Jaya, 1992, hlm. 90-94.
} 
Seorang yang menerima wasiat pengangkatan waris ini dikenal dengan sebutan testamentaire erfgenaam, yaitu dimana ia disamakan. Artinya bahwa sesungguhnya penerima wasiat (ahli waris karena wasiat) dan seorang ahli waris adalah sama menurut undang-undang, dan mereka memperoleh segala hak dan kewajiban dari si meninggal (onder algemene title). ${ }^{30}$

Walaupun kedudukan antara ahli waris ab-intestato dan penerima wasiat erfsterlling ini sama, namun demikian terdapat perbedaan penting diantara keduanya seperti :

1. Ahli waris erfsterlling tidak mengenal ahli waris pengganti, sedangkan dalam ahli waris $a b$-intestato mengenal ahli waris pengganti;

2. Ahli waris erfsterlling tidak dapat menikmati harta boedel sepertinya halnya ahli waris ab-intestato. Ia hanya dapat menikmati apa-apa yang telah dikehendaki dalam akta wasiat erfsterlling.

Penjelasan tentang erfsterlling terdapat pada pasal 954 - 956. Pasal itu berbunyi : Pasal 954 berbunyi, wasiat pengangkatan waris, adalah suatu wasiat, dengan mana si yang mewasiatkan, kepada seorang atau lebih, memberikan harta kekayaan yang akan ditinggalkannya apabila ia meninggal dunia baik seluruhnya maupun sebagian seperti misalnya, setengah, sepertiganya. Artinya isi dari pasal ini wasiat pengangkatan ahli waris ialah suatu wasiat dimana pewaris memberikan kepada satu orang atau lebih harta benda yang ditinggalkannya pada waktu dia meninggal dunia.

Pasal 955 melanjutkan bahwa pada saat si yang mewariskan meninggal dunia, sekalian mereka yang dengan wasiat tersebut diangkat menjadi waris, seperti pun mereka yang demi undang-undang berhak mewarisi sesuatu bagian dalam warisan, demi undang-undang pula memperoleh hak milik atas harta peninggalan si meninggal.

Pasal 956 yang isinya bila timbul perselisihan tentang siapa yang menjadi ahli waris, maka hakim dapat memerintahkan agar harta benda itu disimpan di pengadilan. Lebih lengkap bunyinya adalah, "apabila timbul sesuatu

30 Oemarsalim, Dasar-Dasar Hukum Waris di Indonesia, Jakarta : Rineka Cipta, 1991, hlm. 80-83. Hak-hak itu antara lain : (1) hak saisine hak untuk mengoper atau melanjutkan dari pewaris kepada ahli waris begitu pula dari sipewasiat pada penerima wasiat. (2) hak hereditas petitio, yaitu hak untuk menuntut harta peninggalan pewaris untuk diserahkan kepadanya atau harta peninggalan pewasiat untuk diserahkan kepadanya. 
persengketaan sekitar soal, siapakah ahli waris si meninggal dan siapakah karenanya hak atas kemilikan harta peninggalan tadi, maka hakim adalah berkuasa memerintahkan suatu penyimpanan untuk keadilan atas harta peninggalan itu”.

Dari ketiga pasal diatas, Kitab Undang-Undang Hukum Perdata telah memberikan penjelasan bahwa pengangkatan waris itu merupakan perbuatan hukum yang telah diatur. Artinya ketentuan itu berbunyi bahwa wasiat pengangkatan ahli waris ialah suatu wasiat dimana pewaris memberikan kepada satu orang atau lebih harta benda yang ditinggalkannya pada waktu dia meninggal dunia. $^{31}$

2. Wasiat Hibah (legaat).

Penjelasan tentang hibah (legaat) diatur pada Kitab Undang-Undang Hukum Perdata mulai dari pasal 957- 972. Pasal 957 berbunyi bahwa hibah wasiat adalah suatu penetapan yang khusus, dengan mana si yang mewariskan kepada seorang atau lebih memberikan beberapa barang-barangnya dari suatu jenis tertentu, seperti misalnya segala barang-barangnya bergerak atau tak bergerak, atau memberikan hak pakai hasil atas seluruh atau sebagian harta peninggalannya. ${ }^{32}$ Dari maksud diatas, maka hibah wasiat memiliki unsur :

1. Penetapan khusus;

2. Memberikan satu atau beberapa benda tertentu;

3. Seluruh benda dari satu jenis tertentu; dan

4. Baik itu hak, hak yang dapat dipungut hasilnya.

Seorang yang menerima hibah wasiat ini disebut dengan legataris. Legataris ini berbeda kedudukannya dengan kedudukan penerima wasiat pengangkatan waris. Perbedaannya terletak pada kedudukan legataris itu sendiri sebagai seorang penerima hak khusus sebagaimana disebutkan pada pasal 957. ${ }^{33}$ Dalam konteks ini hak khusus dipahami sebagai hak yang dinyatakan secara khusus untuk menerima hibah wasiat. Apabila hak itu tidak ada maka hibah wasiati itu juga hilang. Hak khusus dikuatkan pada pasal 958 bahwa setiap hibah wasiat yang bersahaja dan tidak bersyarat, memberi hak kepada mereka yang

31 Tamakiran, Asas-Asas Hukum Waris Menurut Tiga Sistem Hukum, Bandung: Pioner Jaya, 1992, hlm. 30-32.

32 Pasal 897 Kitab Undang-Undang Hukum Perdata.

33 Abdul Kadir Muhammad, Hukum Perdata Indonesia, Bandung: Citra Aditya Bakti, 1993, hlm. 200-205. 
dihibahwasiati,semenjak hari meninggalnya si yang mewasiatkannya, untuk menuntut kebendaan yang dihibahwasiatkannya, hak mana menurun kepada sekalian ahli waris atau pengganti haknya.

Secara garis besar Kitab Undang-Undang Hukum Perdata sendiri menjelaskan wasiat dalam 4 tahapan pembahasan. Keempat tahapan pembahasan antara lain yaitu pembahasan: ${ }^{34}$

1. Ketentuan umum wasiat, ketentuan umum ini berbicara tentang pengaturan secara umum terhadap surat wasiat. Hal ini dapat dilihat pada pasal 874 hingga pasal 894. Pokok bahasannya adalah penjelasan umum tentang surat wasiat, isi pernyataan wasiat, kehendak dari si pewasiat, wasiat dibuat secara umum atau secara khusus, hubungan wasiat dengan keluarga-keluarga dari pewasiat, wasiat untuk kepentingan orang miskin, pelaksanaan wasiat tidak membeda-bedakan agama;

2. Kecakapan dalam wasiat, yaitu kecapakan yang dimaksud lebih kepada kemampuan bernalar dalam membedakan keuntungan dan rugi ketika seseorang itu hendak membuat wasiat. Seseorang yang belum berusia 21 tahun tidak dapat membuat wasiat;

3. Batasan dalam wasiat (legitieme portie), ini merupakan penjelasan bahwa ada bagian-bagian dari ahli waris yang harus diberikan kepada ahli waris dalam garis lurus berdasarkan undang-undang yang tidak boleh dihalangi oleh sebuah ketetapan (hibah atau wasiat). Bahkan terhadap sebuah ketetapan yang sengaja dibuat untuk menguntungkan salah satu keluarga baik itu keluarga sedarah dekat ataupun tidak tanpa adanya sebuah penjelasan dapat dianggap sebagai legitieme portie. Legitieme portie ini hendaknya memperhatikan ahli waris, bila ahli waris tidak ada baik itu ahli waris garis keatas, kebawah, dan anak luar kawin yang diakui menurut undang-undang maka harta waris dihibahkan; dan

4. Bentuk wasiat, yaitu bentuk pembuatan surat wasiat yang pada pelaksanaannya dibuat secara akta tulisan tangan sendiri (olografis). Itu

34 M. Wijaya, "Tinjauan Hukum Surat Wasiat Menurut Hukum Perdata", Jurnal Ilmu Hukum Legal Opinion, Edisi 5, Volume 2 Tahun 2014, hlm. 108-110. 
semua dilakukan baik dengan akta umum/terbuka (openbaar), ${ }^{35}$ akta rahasia(geheim) atau akta tertutup.

Penjelasan lain tentang wasiat diatur pula didalam Kompilasi Hukum Islam pada pasal 171, 194 hingga pasal 209. Kompilasi Hukum Islam (KHI) ini diwadahi bukan melalui peraturan perundang-undangan, melainkan diwadahi dengan instruksi Presiden No. 1 Tahun $1991 .{ }^{36}$ Oleh karena itu KHI ini bukan merupakan hukum yang berlaku sebagaimana dijelaskan didalam Undang-Undang No. 12 Tahun 2011 Tentang Pembentukan Peraturan Perundang-undangan.

Karena diwadahi oleh Instruksi Presiden, KHI dianggap bukan sebagai hukum positif di Indonesia. Beberapa pakar mengatakan bahwa KHI merupakan kitab fikihnya ala Indonesia. ${ }^{37}$ Dimana implementasi dari KHI ini digunakan oleh para hakim di Pengadilan Agama sebagai pegangan dalam konteks penyeragaman hukum Islam materiilnya. ${ }^{38}$

Dalam KHI definisi wasiat ada di penjelasan ketentuan umum bab II pasal 171 huruf f. Sedikit penjelasan tentang definisi wasiat ada di Bab II tentang kewarisan di KHI, wasiat didefinisikan sebagai pemberian suatu benda dari pewaris kepada orang lain atau lembaga yang akan berlaku setelah pewaris meninggal dunia. Wasiat dapat dilakukan oleh mereka yang telah berusia 21 tahun terhadap harta benda yang merupakan hak darinya. Adapun wasiat sendiri baru dapat dilaksanakan bila si pewasiat itu sudah meninggal dunia. ${ }^{39}$ Secara umum KHI menjelaskan wasiat dengan ketentuan-ketentuan seperti :

1. Ketentuan kecakapan;

Pada konteks ini, seseorang yang hendak berwasiat sekurang-kurangnya berusia 21 tahun.

2. Syarat-syarat wasiat;

35 Pewasiat menghadap ke notaris untuk menyatakan kehendaknya, kemudian notaris mengkonsep wasiat tersebut hingga jadi dan mengundang pewasiat dengan dihadiri saksi-saksi. Setelah itu notaries membacakan wasiat yang telah dikehendaki pewasiat.

36 Instruksi Presiden No. 1 Tahun 1991, yang isinya menginstruksikan kepada Menteri Agama untuk menyebarkan KHI sebagamana dapat dipergunakan sebagai pedoman dalam menyelesaikan masalah masalah dibidang tersebut.

37 Umar Haris Sanjaya dan Aunur Rahim Faqih, Hukum Perkawinan Islam di Indonesia, Yogyakarta: Gama Media, 2017, hlm. 4-6.

38 Ibid. yang isinya terdiri dari hukum perkawinan, hukum kewarisan, dan hukum perwakafan.

39 Abdul Manan I, "Beberapa Masalah Hukum Tentang Wasiat dan Permasalahannya Dalam Konteks Kewenangan Peradilan Agama”, Mimbar Hukum Aktualisasi Hukum Islam, Edisi IX, No. 38 Tahun 1998, hlm. 15. 
Selain usia kecakapan, syarat wasiat lain antara lain adalah benda obyek wasiat haruslah hak milik si pewasiat. Peralihan hak terjadi setelah meninggalnya si pewasiat. Dilakukan dihadapan notaris. Ada orang yang berwasiat. Ada orang yang menerima wasiat. Ada orang yang diwasiatkan.

3. Bentuk wasiat;

Dalam KHI wasiat mempunyai 2 bentuk yaitu bentuk tertulis ataupun dapat berbentuk lisan. Dalam bentuk tertulis yang dilakukan dihadapan notaris, surat wasiat dalam dilakukan dalam keadaan tertutup.

4. Wasiat kepada ahli waris;

Wasiat kepada ahli waris berlaku bila wasiat tersebut disetujui oleh mereka para ahli waris. Besaran wasiat diperbolehkan sebanyak-banyaknya adalah sepertiga, kecuali bila ada persetujuan dari ahli waris.

5. Batalnya wasiat

Wasiat dapat menjadi batal bila calon penerima wasiat dibatalkan hak wasiatnya berdasarkan putusan hakim yang telah berkekuatan hukum. Dapat pula menjadi batal bila ia tidak mengetahui, menolak, atau tidak bersikap terhadap pemberian wasiat. ${ }^{40}$

6. Saksi dalam wasiat;

Saksi yang harus dihadirkan dalam pembuatan surat wasiat adalah 2 orang saksi. Hal itu berlaku terhadap wasiat secara lisan maupun tulisan dihadapan notaris.

7. Wasiat dalam keadaan tertentu;

Maksud dalam keadaan tertentu ini adalah pembuatan wasiat memungkinkan dilakukan keadaan perang bagi mereka tentara nasional Indonesia atau petugas bela Negara. ${ }^{41}$ Ataupun sedang dalam perjalanan yang hendak pergi ke sesuatu tempat. Terhadap pembuatan wasiat seperti ini harus dilakukan kepada seseorang yang dipercaya dan dihadirkan 2 orang saksi. ${ }^{42}$

8. Larangan dalam wasiat;

Larangan dalam wasiat ini adalah larangan dalam memberikan sebuah wasiat dikarenakan adanya hubungan kepentingan karena suatu pekerjaan. Dalam hal ini pekerjaan dalam konteks kesehatan seperti misalnya pasien (pewasiat) dengan

\footnotetext{
40 Lihat pada pasal 197 Kompilasi Hukum Islam.

41 Lihat pasal 205 Kompilasi Hukum Islam.

42 Lihat pasal 206 Kompilasi Hukum Islam.
} 
perawat, dokter. Disamping itu notaries sebagai pejabat yang mengesahkan surat wasiat dilarang pula secara kepentingan pribadinya mendapat wasiat karena tugasnya. $^{43}$

9. Wasiat wajibah.

Wasiat wajibah diberikan kepada orang tua angkat yang tidak menerima wasiat dan juga bagi anak angkat yang tidak menerima wasiat. Terhadap wasiat wajibah ini mereka sebanyak-banyaknya menerima $1 / 3$ dari harta warisan orang tua angkat/ anak angkatnya. ${ }^{44}$

KHI sebagai kitab fikih nya Indonesia dirumuskan dari ketentuan-ketentuan dalam hukum wasiat Islam. Hukum wasiat Islam tentunya merujuk kepada AlQuran dan hadist yang dalam hal ini sebagai rujukan hukum Islam. Al-quran menyebut wasiat didalam surat

Seseorang yang membuat wasiat dipersyaratkan dengan syarat tertentu. Syarat itu meliputi syarat kecakapan dan akal budi. ${ }^{45}$ Seseorang yang telah mencapai usia 18 tahun $^{46}$ atau ia telah dinyatakan dewasa dan mereka dalam keadaan sehat akal budi nya pada saat pembuatan wasiat. Tetapi jika ia mengalami gangguan akal budi setelah wasiat itu dibuat, maka wasiat yang dibuat itu tetap berlaku dan sah. Kerusakan akal budi setelah dibuatnya wasiat tidak membuat wasiat menjadi gugur atau batal. ${ }^{47}$

Menurut Kitab Undang-Undang Hukum Perdata wasiat dapat dilakukan dalam 3 bentuk, dimana ini diartikan dari pasal 931 yang berbunyi "suatu wasiat hanya boleh dinyatakan baik dengan akta tertulis sendiri atau olografis, baik dengan akta umum ataupun akta rahasia atau tertutup". ${ }^{48}$ Berbeda dengan Kitab Undang-Undang Hukum Perdata, Kompilasi Hukum Islam membuka bentuk wasiat secara lisan dengan dua orang saksi, tulisan dengan dua orang saksi, atau dengan notaris. ${ }^{49}$

43 Lihat pasal 207-208 Kompilasi Hukum Islam.

44 Lihat pasal 209 Kompilasi Hukum Islam.

45 H.F.A Vollmar, Pengantar Studi Hukum Perdata, Jilid I, Cetakan 4, Jakarta: Raja Grafindo Persada, 1996, hlm. 410-415.

4618 tahun Pada Kitab Undang-Undang Hukum Perdata sedangkan KHI mensyaratkan 21 tahun.

47 Asyhari Abta dan Djunaidi Syakur, Ilmu Waris Deskripsi Islam Praktis dan Terapan, Surabaya: Pustaka Hikmah Perdana, 2005, hlm. 50-60.

48 Kitab Undang-Undang Hukum Perdata pasal 931.

49 Kompilasi Hukum Islam Pasal 195 ayat (1). 
Wasiat yang dilakukan secara lisan apabila dicermati lebih kepada perwujudan hukum Islam (fiqh di Indonesia) yang fleksibel. Kedepan wasiat lisan cenderung tidak digunakan (relevan) lagi, mengingat masyarakat sekarang ini membuat wasiat dalam bentuk akta untuk kepastian hukum. ${ }^{50}$ Pada maksud ini beberapa sarjana muslim menegaskan bahwa sesungguhnya akta otentik akan lebih terpercaya pembuktian di masa sekarang dan masa yang akan datang. Oleh karena itu masyarakat cenderung membuat wasiat dalam bentuk akta atau tulisan. $^{51}$

Bentuk wasiat secara umum dilakukan dengan tertulis, baik ditulis oleh si pewasiat itu sendiri, atau dibantu oleh notaries. Bentuk itu antara lain dilakukan dengan cara $:{ }^{52}$

1. Wasiat umum (openbaar); dimana pewasiat membuat wasiatnya dihadapan notaries dengan dibuatnya akta yang dihadiri duar orang saksi

2. Wasiat tertulis (olographis); dimana wasiat ditulis oleh sipembuat wasiat itu sendiri (eigendhadig), baru kemudian diserahkan kepada notaries untuk disimpan (gedeponeerd).

3. Wasiat tertutup; dimana wasiat ini dibuat sendiri oleh pewasiat kemudian ditutup (disegel) dan diserahkan kepada notaries dengan dihadiri empat orang saksi. Yang tahu isi dari wasiat ini hanya sipembuat wasiat itu sendiri.

4. Wasiat lisan; ini dilakukan secara lisan dihadapan dua orang saksi. Wasiat ini cenderung dilakukan bila terjadi bila dalam situasi yang genting sehingga tidak sempat untuk melakukannya secara tertulis.

\section{Tinjauan eksekusi terhadap wasiat}

Banyak kajian yang telah membahas pelaksanaan wasiat, dari kajian tersebut sebagian besar mengkaji lebih kepada praktek perbuatan hukum /proses pelaksanaan wasiat. Dalam hal ini penulis cenderung menjelaskan pelaksanaan wasiat dari sudut pandang eksekusi untuk dilaksanakannya wasiat. ${ }^{53}$ Dengan mengetahui kekuatan eksekusi wasiat, maka akan diketahui secara konkrit kedudukan harta yang diwasiatkan dihadapan harta warisan.

\footnotetext{
50 Noor shofa, "Jangkauan kewenangan mengadili Pengadilan Agama Dalam Perkara Wasiat", Mimbar Hukum, Edisi IX No. 39 Juli -Agustus, 1998, hlm. 30-35.

51 M.J.A. Van Mourik, Studi Kasus Hukum Waris, Bandung: Eresco, 1993, hlm. 75.

52 J. Satrio, Hukum Waris, , Cetakan 1, Bandung: Citra Aditya Bakti, 1990, hlm. 160-165.

53 Abdul Manan, Aneka Masalah Hukum Perdata Islam di Indonesia, Jakarta: Kencana Prenada Media Group, 2006, hlm. 160.
} 
Wasiat yang menjadi obyek penelitian penulis ini terjadi pembatalan oleh Putusan Pengadilan, oleh karena itu wasiat tidak diindahkan untuk dilaksanakan. Hal ini terjadi karena sengketa terhadap wasiat yang diajukan di pengadilan Negeri Bantul dan tertuang dalam perkara register No. 09/Pdt.G/2004/PN.Btl tanggal 18 September 2004. Terhadap perkara tersebut Pengadilan memutuskan bahwa sebuah wasiat (erfsterling) yang isinya adalah jatah harta yang telah dibagikan kepada masing-masing para ahli waris dinyatakan sebagai harta warisan yang harus diselesaikan dengan hukum waris. Pada konteks ini, seharus para penerima wasiat sekaligus para ahli waris sesungguhnya tinggal melaksanakan/ mengeksekusi wasiat. Tetapi itu tidak dieksekusi oleh penerima wasiat, sehingga menimbulkan sengketa bagi mereka.

Dalam wasiat tidak mengenal asas eksekusi pelaksanaan wasiat, atau asas harus dilaksanakannya wasiat, beberapa unsur yang dapat dijadikan asas dalam wasiat yang dipahami saat ini adalah tentang $:^{54}$ kecapakan, ada pewasiat, ada penerima wasiat, ada barang yang diwasiatkan, ada pernyataan, ada saksi, ada batasan wasiat, batalnya wasiat. Jadi terhadap suatu wasiat yang telah dibuat ada sebuah kemungkinan untuk tidak dilakukan/eksekusi karena penerima wasiat (baik sendiri atau bersama-sama) sengaja tidak mau mengeksekusi wasiat ini.

Terhadap keinginan untuk tidak mengeksekusi wasiat ini dapat saja menimbulkan sengketa wasiat kedepannya, dengan konsekuensi sengketa itu dibawa ke sidang pengadilan. Dalam sidang pengadilan, wasiat itu dapat saja dibatalkan oleh hakim karena adanya suatu sengketa. Oleh karena itu kedudukan dari wasiat ini dapat saja di kalahkan oleh kedudukan hukum waris, padahal wasiat adalah bagian dari kajian hukum waris. Dalam sudut pandang lain lebih kuat mana antara surat wasiat dan hukum waris $?^{55}$ untuk diindahkan. ${ }^{56}$ beberapa negara lain pun memberlakukan pelaksanaan wasiat yang berbeda-beda, ada yang dibatasi penerimanya ada yang tidak dibatasi. ${ }^{57}$

\footnotetext{
54 Ahmad Rofiq, Hukum Islam di Indonesia, Jakarta: Raja Grafindo Persada, 2003, hlm. 450 .

55 Fatum Abubakar, "Pembaruan Hukum Keluarga:Wasiat Untuk Ahli Waris (Studi Komparatif Tunisian, Syiria, Mesir, Dan Indonesia)," Hunafa Jurnal Studia Islamika, Vol. 8 No. 2 Desember, 2011, Palu: LP2M IAIN hlm. 260-264.

56 Beberapa hal ada pada konten, "Bolehkah para ahli waris tidak mengindahkan surat wasiat ?", http://m.hukumonline.com/klinik/detail/1t56a9bd466a9a3/bolehkah para-ahli waristidak-mengindahkan-surat-wasiat, diakses pada 3 Januari 2017.

57 Ibid.
} 
Pada perspektif islam, sarjana hukum Islam menjelaskan bahwa seseorang atau badan yang dapat menerima wasiat adalah mereka yang cakap dan bukan dari ahli waris. Hal ini sesuai dengan hadist Rasulullah SAW yang diriwayatkan Tirmidzi yang isinya adalah tidak sah wasiat kepada ahli waris. ${ }^{58}$ Terhadap hadis ini, ada kalangan ulama fiqih yang menjelaskan wasiat boleh untuk ahli waris sepanjang ahli waris lainnya ikut menyetujui. ${ }^{59}$ Takutnya nanti setiap wasiat yang telah dibuat lalu timbul sengketa, kemudian digugat, kalau semua wasiat digugat dan tidak dieksekusi justru nanti wasiat bukan lagi menjadi kehendak terakhir dari pewaris. Karena wasiat yang jadi sengketa itu dapat dibatalkan di Pengadilan.

Pengadilan mempunyai kewenangan untuk memeriksa dan memutus perkara sesuai dengan kompetensinya. Dalam perkara ini Pengadilan Negeri Bantul menjadi tempat dimohonkannya sengketa eksekusi wasiat yang dijadikan obyek penelitian penulis. Pada putusan di tingkat pertama pada putusan No.09/Pdt.G/2004/PN.Btl, diadili bahwa wasiat yang dibuat oleh pewasiat sekaligus pewaris kepada mereka penerima wasiat (semuanya adalah ahli waris) untuk dibatalkan dan kemudian dinyatakan tidak berlaku. Hal ini terdapat pada di amar putusan poin ke 3 yang bunyinya : "Menyatakan bahwa tanah obyek sengketa adalah harta peninggalan (harta warisan) dari almarhum Bp. Notodihardjo yang belum dibagi waris".

a. Kedudukan Wasiat terhadap waris berubah disidang Pengadilan

Dalam putusan No.09/Pdt.G/2004/PN.Btl jo Putusan Pengadilan Tinggi Daerah Istimewa Yogyakarta No. 12/Pdt/2005/PT.Y jo Putusan MA No. 2332 K/Pdt/2005 dapat diketahui bahwa wasiat yang dibuat telah memenuhi unsurunsur yang terkandung dalam pembuatan wasiat. Unsur itu diuraikan dalam kasus putusan ini maka $:^{60}$

1) Testament adalah suatu "akta", kata mana menunjukkan suatu syarat bahwa testamen harus berbentuk tertulis. Testamen dapat dibuat dengan akta bawah tangan maupun dengan akta otentik. Akta tersebut harus mempunyai isi yang pada intinya berupa pernyataan atau suatu kehendak dari si pewasiat.

\footnotetext{
8 Ahmad Rofiq, Op.cit., hlm. 450.

Ibid.

Simanjuntak, Op.cit., hlm. 267.
} 
Pada obyek penelitian putusan ini, fakta mengungkapkan beberapa poinpoin bahwa pembuatan wasiat ini dibuat dalam 4 bentuk akta (wasiat, surat kuasa, surat wasiat bersama ahli waris, surat persetujuan waris). Akta ini dibuat tidak hanya dengan surat pernyataan wasiat yang dibuat oleh si pewasiat, melainkan juga kesepakatan bersama antara pewasiat dan para ahli waris. Wasiat itu antara lain berdasarkan surat wasiat yang dibuat bapak Notodiharjo dibawah tangan yang ditujukan untuk bapak Benny Asriyanto. Surat wasiat tersebut ditandatangani oleh mereka berdua pada tanggal 16 Maret 1974. Yang isinya "bapak Notodiharjo memberikan surat wasiat kepada satu-satunya anak kami yang pertama, Benny Asriyanto bahwa sebidang tanah sawah yang terletak di sebelah barat kampung Babadan, Banguntapan, Bantul, tercatata No. persil 96, klas IV, luas $4735 \mathrm{M}^{2}$. kami berikan anak kami tersebut diatas untuk dimiliki turun temurun."

Untuk mempertegas wasiat itu, pada hari yang sama juga ditandatangani Surat kuasa antara Notodiharjo (pihak I) dan Benny Asriyanto (pihak II) tertanggal 16 Maret 1974 dengan materai. Yang bunyinya "selaku pihak I menyerahkan/menguasakan kepada Benny Asriyanto selaku pihak II sebidang tanah sawah dan telah ada bangunannya ruamh tembok yang terletak di : sebelah barat Desa Babada, Gedong Kuning/Kalurahan Banguntapan/Kecamatan : Kotagede/Yogyakarta/Kabupaten Bantul, Yogyakarta, yang tercatat No. persil 96.S. Klas IV. Luas : $\pm 4735 \mathrm{M}^{2}$. Dan selanjutnya saya kuasai penuh untuk mengurusi dan berhadapan kehadapan instansi pemerintah yang bersangkutan. Surat kuasa ini kamu buat tanpa tekanan orang lain dan siapapun kecuali keluar dari hati sanubari saya sendiri".

Pada 30 Desember 1982 bapak Notodihardjo, membuat surat wasiat yang diperuntukkan bagi anak keturunannya yang berjumlah 10 orang. Tujuan dari surat wasiat ini guna membagi-bagikan harta kekayaannya berupa tanah dari bapak Notodihardjo kepada anak-anaknya. Adapun pembagian tanah tersebut diperuntukkan kepada putra/putrinya, antara lain :
No. Nama
Putra/putri ke
Lokasi
1. Benny Asriyanto
Putra 1 (pertama)
Gedongkuning Btp
2. Herwan Sriyono
Putra 2 (kedua)
Jetis Petinggen
3. Ny. Asiyah
Putri 3 (ketiga)
Tempelsari 

4. Handoko Slamet R Putra 4 (keempat) Tempelsari
5. Bambang Setyo
Putra 5 (kelima)
Kledokan
6. Harmintiasih
Putri 6 (keenam) Tempelsari
7. Gunarsiwibisono
Putra 7 (ketujuh)
Semarang
8. Srirahayu
Putri 8 (kedelapan)
Ambarukmo/pelem
9. Ery Setyaningsih
Putri 9 (kesembilan) Tempelsari
10. Edy Santoso
Putra 10 (kesepuluh) Tempelsari

Dengan adanya surat wasiat yang dibuat dan ditanda tangani oleh bapak Notodihardjo tersebut maka kehendak dari beliau yang dibuat pada tanggal 30 Desember 1982 sudah dinyatakan sebagai perbuatan hukum. Dengan begitu sepatutnya wasiat ini dilaksanakan oleh para penerima wasiat.

Untuk mempertegas wasiat tertanggal 30 Desember 1982, maka dibuat surat persetujuan waris terhadap pembagian harta kekayaan berupa tanah itu kepada anak-anaknya. Surat persetujuan waris ini dibuat mengacu pada surat wasiat yang dibuat pada tanggal 30 Desember 1982.

Surat persetujuan waris ini dibuat sebagai dasar bahwa para ahli waris yang juga penerima wasiat telah sepakat dan setuju untuk menerima bagianbagian harta peninggalan Notodihardjo sebagaimana telah dibagikan didalam surat wasiat. Surat persetujuan waris ini ditujukan secara khusus kepada Benny Asriyanto sebagai yang diberi dan yang memberi adalah bapak Notodihardjo. Dalam surat persetujuan waris ini ditanda tangani seluruh ahli waris bapak Notodihardjo dimana mereka menjadi para penggugat dalam putusan ini. Surat persetujuan waris ini telah diketahui dan diberi cap oleh Kepala Desa Catur Tunggal pada tanggal 29 Januari 1999 dan dikuatkan oleh Camat Depok pada tanggal 1 Februari 1999. Mengetahui dari kepada Desa dan Camat ini dengan maksud untuk menjelaskan bahwa Bahwa Benny Asriyano adalah benar-benar penduduk Desa Catur Tunggal, Depok. Serta menjelaskan bahwa bapak Notodihardjo adalah benar penduduk Desa Catur Tunggal yang telah meninggal pada tanggal 16 Januari 1995. Artinya surat persetujuan waris ini dibuat dan diketahui oleh Kepala Desa dan Camat sebagaimana domisili tinggal terakhir pewaris.

Bunyi surat persetujuan waris adalah "adapun yang bertanda tangan diatas tersebut semuanya menyetujui bahwa sebidang tanah atas nama Bp 
Notodihardjo yang terletak di sebelah barat kampung Babadan, Banguntapan Bantul, S. 96 / IV = $4735 \mathrm{M}^{2}=$ dilintirkan kepada : Nama : Benny Asriyanto. Umur : 38 th. Alamat : Babadan, Banguntapan, Bantul. Kemudian agar surat ini berlaku kepada pemerintah yang membutuhkan”.

Dengan adanya surat wasiat yang dibuat oleh bapak Notodihardjo yang berisi tentang pembagian jatah tanah beserta lokasi-lokasinya kepada anakanaknya dan kemudian diperkuat dengan surat persetujuan waris yang ditanda tangani oleh seluruh ahli waris dari bapak Notodihardjo tentang pelintiran tanah sesuai lokasi yang ada pada surat wasiat yaitu tanah yang terletak di sebelah barat kampung Babadan, Banguntapan Bantul, S. 96 / IV = $4735 \mathrm{M}^{2}$ kepada Benny Asriyanto, maka demi hukum ini sudah menjadi sebuah perbuatan hukum dan telah menjadi hak yang melekat pada Benny Asriyanto.

2) Pada prinsipnya suatu testament pastilah berisi suatu pernyataan kehendak atau persyaratan kehendak.

Pernyataan ini berarti merupakan perbuatan hukum sepihak. Tindakan ini adalah tindakan dari seseorang yang sudah dianggap cukup untuk menimbulkan akibat hukum apa yang dikehendakinya. Wasiat ini menimbulkan suatu perikatan, tetapi perikatan ini tidak dibuat atas dasar perjanjian yang adanya kata kesepakatan diantara orang yang mengikatkan diri. Karena wasiat merupakan pernyataan yang dibuat sepihak, maka tanpa adanya kesepakatan suatu wasiat sudah dianggap sah. ${ }^{61}$

Pernyataan kehendak yang terdapat pada obyek penelitian ini antara lain :

a) Bapak Notodiharjo memberikan surat wasiat kepada satu-satunya anak kami yang pertama, Benny Asriyanto bahwa sebidang tanah sawah yang terletak di sebelah barat kampung Babadan, Banguntapan, Bantul, tercatata No. persil 96, klas IV, luas $4735 \mathrm{M}^{2}$. kami berikan anak kami tersebut diatas untuk dimiliki turun temurun.

b) Kehendak untuk membagi-bagikan harta kekayaannya berupa tanah dari bapak Notodihardjo kepada anak-anaknya.

61 J. Satrio, Hukum Waris, Bandung: Alumni, 1992, hlm. 180. 
3) Suatu wasiat berlaku apabila si pembuat wasiat itu telah meninggal dunia.

Jadi unsur kehendak seseorang itu terjadi setelah adanya pewasiat yang meninggal dunia. Hal ini diungkapkan bahwa wasiat merupakan kehendak terakhir dari seseorang. ${ }^{62}$

Pada tahun Pada 16 Januari 1995 bapak Notodiharjo telah meninggal dunia, ${ }^{63}$ tetapi sejak meninggal pada tahun 1995 hingga tahun $2001^{64}$ tanah tersebut belum dilakukan eksekusi wasiat sesuai dengan surat wasiat.

4) Wasiat merupakan kehendak yang dapat dicabut oleh yang membuatnya.

Ketentuan ini dipakai untuk menetapkan apakah tindakan hukum harus dibuat dalam bentuk surat wasiat atau cukup dengan bentuk lain. Pencabutan terhadap surat wasiat ini memberikan pengertian bahwa tidak semua yang diinginkan oleh si pembuat wasiat belum tentu dapat dilaksanakan atau diperbolehkan. Jadi harus tidak melanggar ketentuan-ketentuan yang ada.

Pada obyek penelitian ini wasiat tidak dicabut oleh si pembuat, melainkan dijadikan sengketa oleh ahli waris dari penerima wasiat. Oleh karena itu wasiat diajukan sengketa di pengadilan. Pada pengadilan wasiat itu diputus dan dinyatakan sebagai obyek waris.

a) Apakah surat wasiat harus dilaksanakan/dieksekusi ?

Tidak ada teori atau doktrin yang dapat memaksakan wasiat untuk dieksekusi/dilaksanakan ketika pembuat wasiat itu meninggal dunia. Hal ini terjadi karena pelaksanaan wasiat selalu beriringan dengan pelaksanaan waris. Bila dalam pelaksanaan wasiat terkendala, dapat dijelaskan bahwa ada sengketa dalam waris. Pada obyek penelitian ini obyek wasiat sama dengan obyek warisan, sehingga para ahli waris hendak menyelesaikannya dengan pembagian waris. Walaupun sebelumnya telah ada penyelesaian pembagian harta melalui wasiat. Pada konteks ini kehendak dari wasiat dapat tidak diindahkan bila para ahli waris tidak menghendaki sesuai dengan wasiat.

Apabila para ahli waris yang juga sebagai penerima wasiat ada yang menghendaki dan ada yang tidak menghendaki, maka ini bagian dari sengeketa dengan penyelesaiannya berujung di Pengadilan.

62 Ibid.

63 Surat kematian nomor 06.DS.CT/Ksr/1/1995 tertanggal 19 Januari 1995.

64 Tahun dimana Benny Asriyanto meninggal, yaitu pada 13 Februari 2001. 
Pengadilan sebagai lembaga peradilan sesuai dengan kewenangannya dapat memeriksa dan memutus perkara yang diajukan. Terhadap sengketa wasiat, pengadilan kebanyakan memeriksa perkara wasiat dikarenakan hak wasiat dari anak angkat tidak dijalankan oleh ahli waris, ${ }^{65}$ atau sebaliknya harta peninggalan diwasiatkan kepada anak angkat sehingga ahli waris tidak kebagian. Terhadap sengketa wasiat seperti diatas, sebagian besar sengketa diajukan dengan permohonan agar wasiat dibatalkan. Sengketa wasiat yang dibuat pada periode tahun 1974 dan periode 1982 ini belum menggunakan mekanisme peradilan agama, tetapi melalui pengadilan negeri. ${ }^{66}$ Pengadilan agama berwenang memeriksa perkara sengketa wasiat bagi warga Muslim bila wasiat itu dibuat setelah berlakunya Undang-Undang No. 7 Tahun $1989 .^{67}$

Pada penelitian ini wasiat tidak dapat dieksekusi karena wasiat menjadi obyek sengketa wasiat. Ketika sengketa telah diajukan ke Pengadilan, dan pengadilan memutuskan untuk menerima dan memeriksa perkara, maka sengketa itu sepenuhnya diputus oleh Pengadilan.

Pada penelitian ini wasiat itu menjadi sengketa berawal dari penguasaan harta/tanah yang sudah diwasiatkan oleh pewasiat (bapak Notodihardjo) kepada penerima wasiat (Benny Asriyanto). Ketika penerima wasiat meninggal dunia, ternyata diketahui bahwa tanah yang diwasiatkan belum diubah nama kepemilikannya. Artinya tanah wasiat tersebut masih berkepemilikan atas nama pewasiat. Ahli waris dari pewasiat (penggugat) merasa itu adalah tanah/harta dari pewasiat yang belum dibagi waris. Ahli waris dari penerima wasiat merasa bahwa itu adalah haknya, karena semua ahli waris dari pewasiat sudah mendapatkan jatah/bagiannya masing-masing sesuai dengan surat wasiat dan surat persetujuan waris yang dibuat dan ditanda tangani oleh bapak Notodihardjo beserta ahli warisnya pada tanggal 30 Desember 1982.

65 Sirman Dahwal, “Abstraksi, Beberapa masalah hukum tentang wasiat", Repository.unib.ac.id/486/1/4-judul tentang wasiat.pdf, diakses pada 10 Januari 2017.

66 Pada konteks ini mengacu pada Kitab Undang-Undang Hukum Perdata pasal 835 bahwa tuntutan ahli waris terkait harta warisa baru kedaluarsa dalam tenggang waktu 30 tahun, sedangkan periode 1982 hingga 2004 itu baru berjalan 22 tahun.

67 Ibid. 
b) Siapa yang dapat membatalkan ?

Menurut Hukum Islam, wasiat adalah perbuatan yang dilakukan dengan kemauan hati dalam keadaan apapun. Atas dasar kemauan hati itu, tidak bisa wasiat itu untuk tidak dilaksanakan/dieksekusi. Sepanjang itu sesuai dengan kehendak pewasiat dan sesuai syariat islam maka wasiat itu wajib dilakukan, bahkan terhadap putusan hakim. ${ }^{68}$ Oleh karena itu wasiat yang telah dibuat sepatutnya dilaksanakan atau dieksekusi oleh mereka para penerima wasiat dan ahli waris dari pewasiat. ${ }^{69}$.

Secara spesifik KUHPerdata menjelaskan beberapa hal sengketa wasiat sama halnya dengan sengketa dalam urusan waris. Pasal 834 KUHPerdata berbunyi, "to "tiap-tiap waris berhak memajukan gugatan guna memperjuangkan hak warisnya, terhadap segala mereka, yang baik atas dasar hak yang sama, baik tanpa dasar sesuatu hak pun menguasai seluruh atau sebagian harta peninggalan, seperti pun terhadap mereka, yang secara telah menghentikan penguasaannya. Ia boleh memajukan gugatan itu untuk seluruh warisan, jika ia adalah waris satu-satunya, atau hanya untuk sebagian, jika ada beberapa waris lainnya. Gugatan demikian adalah untuk menuntut, supaya diserahkan kepadanya, segala apa yang dengan dasar hak apapun juga terkandung dalam warisan beserta segala hasil, pendapatan dan ganti rugi, menurut peraturan termaktub dalam bab ketiga buku ini terhadap gugatan akan pengembalian barang milik".

Ditambahkan pada pasal selanjutnya yakni pasal 835 bahwa : “tiap tuntutan demikian gugur karena kedaluarsa dengan tenggang waktu selama tiga puluh tahun". Dengan demikian, sengketa wasiat yang melibatkan ahli waris dapat menjadi batu ganjalan dalam melaksanakan/mengeksekusi wasiat. Mengingat ahli waris mempunyai hak untuk mengajukan tuntutan penyelesaian sengketa. Penyelesaian sengketa kembali pada hakim dalam memeriksa perkara dan mengadili sengketa apakah akan mengeksuki wasiat atau memberikan pada ahli waris.

68 Hasbi Ash-Shidieqy, Fiqh Mawaris, Semarang: Pustaka Rizki Putra, 2001, hlm. 270-273.

69 Anwar Sitompul dan Fara'id, Hukum Waris Islam Dalam Waris Islam dan Masalahnya, Surabaya: Al-Ikhlas, 1984, hlm. 60.

70 Kitab Undang-Undang Hukum Perdata pasal 834. 
KHI menjelaskan tentang kewenangan pengadilan dalam membatalkan sebuah wasiat pada pasal 197 ayat 1 KHI melalui putusan hakim yang telah berkekuatan hukum tetap. Hal itu antara lain :

1. Dipersalahkan karena telah membunuh atau mencoba membunuh atau menganiaya berat kepada pewasiat;

2. Dipersalahkan secara memfitnah telah mengajukan pengaduan bahwa pewasiat telah melakukan sesuatu kejahatan yang diancam hukuman lima tahun penjara atau hukum yang lebih berat;

3. Dipersalahkan dengan kekerasan atau ancaman mencegah pewasiat untuk membuat atau mencabut atau merubah wasiat untuk kepentingan calon penerima wasiat;

4. Dipersalahkan telah menggelapkan atau merusak atau memalsukan surat wasiat dan pewasiat.

Pada penelitian ini wasiat yang tidak dilaksanakan dan menimbulkan sengketa pada akhirnya diajukan ke Pengadilan. Hakim memberikan pertimbangan untuk membatalkan wasiat dan menjadikan segala isi wasiat berupa harta kekayaan pewasiat itu menjadi harta warisan. Itu terdapat pada pertimbangan hakim, hakim memutus bahwa wasiat itu dinyatakan sebagai harta warisan. Hal ini tercantum pada poin ke tiga dan keempat putusan hakim.

Pertimbangan Hakim Pengadilan Bantul No. 09/Pdt.G/2004/PN.Btl tanggal 18 September 2004 bahwa :

1. Menimbang eksepsi dari para tergugat tidak dapat diterima (vide : putusan MARJ, tanggal 27 Februari 1973 , No. 1177 K./SIP./1975).

2. Menimbang terhadap para tergugat atau siapa saja yang menguasai atau memperoleh hak dari tergugat I dan tergugat II, untuk menyerahkan tanah obyek sengketa pada para penggugat dalam keadaan kosong serta bebas dari beban apapun dna bila perlu dengan bantuan aparat hukum untuk kepentingan pembagian waris.

3. Menimbang terkait batas, sejak tangun 1989 pernah terjadi penimbunan tanah dan terjadi perubahan dengan tinggi timbunan \pm 30 meter, dengan demikian sebaiknya dilakukan pengukuran terlebih dahulu. 
4. Menimbang karena subyek dan pihak-pihak yang terlibat tidak lengkap maka selayaknya gugatan tidak dapat diterima.

5. Menimbang gugatan tidak dapat diterima, maka biaya yang timbul dibebankan kepada para penggugat.

Atas dasar pertimbangan diatas, hakim di pengadilan memberikan putusan :

1. Menyatakan eksepsi para penggugat tidak dapat diterima

2. Menerima dan mengabulkan gugatan penggugat untuk sebagian

3. Menyatakan bahwa tanah obyek sengketa adalah harta peninggalan (harta warisan) dari almarhum Bp. Notodihardjo yang belum dibagi waris.

4. Menyatakan dan menetapkan bahwa para penggugat, para tergugat, para tergugat berkepentingan adalah ahli waris janda, anak, cucu yang sah dari almarhum Bp. Notodihardjo yang berhak mewaris atas tanah obyek sengketa.

5. Menyatakan bahwa para tergugat telah melakukan perbuatan melawan hukum.

6. Menghukum para tergugat atau siapa saja yang mendapat hak dari pada mereka untuk menyerahkan tanah obyek sengketa kepada para penggugat dalam keadaan kosong dan tanpa beban apapun untuk dibagi waris, apabila perlu dengan bantuan polisi.

Oleh karena itu surat wasiat sepatutnya dilaksanakan/dieksekusi oleh mereka yang berkepentingan sebagai akibat adanya surat wasiat. Mereka yang dimaksud oleh penulis dapat saja penerima wasiat, ataupun ahli waris dari si pewasiat. Bila terjadi sengketa, dan sengketa tidak berujung selesai, maka penyelesaian dapat diajukan ke pengadilan. Pengadilan yang berwenang untuk memeriksa dan memutus sengketa yang diajukan sepanjang itu sesuai dengan kompetensinya. Pada konteks ini, keberadaan wasiat dapat saja tidak dilaksanakan/dieksekusi kembali pada putusan dan pertimbangan hakim. 


\section{SIMPULAN}

Berdasarkan permasalahan dan hasil pengkajian dalam bentuk analisis terhadap putusan pengadilan dan dokumen yang ada, dapat disimpulkan bahwa kedudukan surat wasiat yang sah sebagai perbuatan hukum sebagaimana memenuhi unsur-unsur pembuatan wasiat sepatutnya dilaksanakan oleh mereka para penerima wasiat yang dalam hal ini penerima wasiat juga dalam kedudukannya sebagai ahli waris. Wasiat adalah perbuatan yang dilakukan dengan kemauan hati si pewasiat, atas dasar kemauan hati itu, tidak bisa wasiat itu untuk tidak dilaksanakan/dieksekusi.

Sepanjang itu sesuai dengan kehendak pewasiat dan sesuai syariat islam maka wasiat itu wajib dilakukan, bahkan terhadap putusan hakim. Jadi wasiat sepatutnya dilaksanakan sepanjang itu tidak berkaitan dengan harta kekayaan ahli waris. Wasiat yang berkaitan dengan harta kekayaan ahli waris kemudian ahli waris tidak menghendaki maka dapat menimbulkan sengketa. Terhadap sengketa itu dapat saja wasiat diajukan ke pengadilan. Sengketa wasiat yang diajukan ke pengadilan kedudukannya menjadi ditangan hakim sidang pengadilan.

Untuk dapat melaksanakan/mengeksekusi wasiat hendaknya memperhatikan keadaan dari ahli waris. Ahli waris yang mempersengketakan wasiat mempunyai hak untuk dapat membatalkan eksekusi wasiat. Terlebih bila ahli waris mengajukan gugatan terhadap sengketa dalam wasiat. Ketika sengketa itu sudah diperiksa oleh pengadilan dan diputus oleh pengadilan, pelaksanaan wasiat kembali pada amar putusan pengadilan. Oleh karena itu wasiat tidak absolut dapat dieksekusi.

\section{DAFTAR PUSTAKA}

\section{Buku:}

Abta, Asyhari dan Djunaidi Syakur. 2005. Ilmu Waris Deskripsi Islam Praktis dan Terapan, Surabaya: Pustaka Hikmah Perdana

Adi, Riyanto. 2004. Metodologi Penelitian Sosial dan Hukum. Jakarta: Graint

Afandi, Ali. 1997. Hukum Waris, Hukum Keluarga, dan Hukum Pembuktian Menurut Kitab Undang-Undang Hukum Perdata ( $B W)$, Jakarta: Rineka Cipta 
Arikunto, Suharsimu. 1996. Prosedur Penelitian Suatu Pendekatan Praktek, Jakarta: Rineka Cipta

Ash-Shidieqy, Hasbi. 2001. Fiqh Mawaris, Semarang: Pustaka Rizki Putra

Efendi M. Zein, Satria. 2004. Problematika Hukum Keluarga Islam Kontemporer, Jakarta: Prenada Media

Harahap, Yahya. 2003. Kedudukan, Kewenangan dan Acara Peradilan Agama, Jakarta: Sinar Grafika

Haris Sanjaya, Umar dan Aunur Rahim Faqih. 2017. Hukum Perkawinan Islam di Indonesia, Yogyakarta: Gama Media

Kadir Muhammad, Abdul. 1993. Hukum Perdata Indonesia, Bandung: Citra Aditya Bakti

Kartasapoetra, G dan R. G. Kartasapoetra. 1994. Pembahasan Hukum Benda, Hipotek, dan Warisan, Jakarta: Bumi Aksara

Mamudji, Sri, et, al. 2005. Metode Penelitian dan Penulisan Hukum, Jakarta: Badan Penerbit Fakultas Hukum Universitas Indonesia

Manan, Abdul. 2006. Aneka Masalah Hukum Perdata Islam di Indonesia, Prenada Jakarta: Media Group

Mulyadi. 2008. Hukum Waris Tanpa Wasiat, Semarang: Badan Penerbit Universitas Diponegoro Semarang

Oemarsalim. 1991. Dasar-Dasar Hukum Waris Di Indonesia, Jakarta: Rineka Cipta 
Ramulyo, Idris. 2003. Perbandingan Pelaksanaan Kewarisan Islam Dengan Kewarisan Menurut Kitab Undang-Undang Hukum Perdata (BW), Jakarta: Sinar Grafika

Rato, Dominikus. 2011, Hukum Perkawinan dan Waris Adat (System Kekerabatan, Bentuk Perkawinan, dan Pola Pewarisan Adat di Indonesia, Surabaya: Lasbang Yustisia

Rofiq, Ahmad. 2003. Hukum Islam di Indonesia, Jakarta: Raja Grafindo Persada

Sabiq, Sayid. 1988. Fikih Sunnah, Bandung: Al-Ma'arif

Satrio, J. 1990. Hukum Waris. Cetakan 1, Bandung: Citra Aditya Bakti 1992. Hukum Waris, Bandung: Alumni

Setiady, Tolib. 2013. Intisari Hukum Adat Indonesia (Dalam Kajian Kepustakaan), Bandung: Alfabeta

Simanjuntak. 1999. Pokok-Pokok Hukum Perdata, Jakarta: Djambatan

Sitompul, Anwar dan Fara'id. 1984, Hukum Waris Islam Dalam Waris Islam dan Masalahnya, Surabaya: Al Ikhlas

Soekamto, Soerjono. 2007. Penelitian Hukum Normatif (Suatu Tinjauan Singkat), Jakarta: Raja Grafindo Persada

Soekanto, Soerjono dan Sri Mamudji. 2007. Penelitian Hukum Normatif Suatu Tinjauan Singkat. Cetakan ke-10, Jakarta: Raja Grafindo Persada

Subekti. 1994. Pokok-Pokok Hukum Perdata, Jakarta: Intermasa

Sudiyat, Iman. 1981. Hukum Adat, Sketsa Asas, Yogyakarta: Liberty 
Tamakiran. 1992. Asas-Asas Hukum Waris Menurut Tiga Sistem Hukum, Bandung: Pioner Jaya

Thaib, Hasbalah. 1992. Hukum Benda Menurut Islam, Medan: Fakultas Hukum Universitas Dharmawangsa

Thalib, Sajuti. 2000. Hukum Kewarisan Islam di Indonesia, Jakarta: Sinar Grafika

Usman, Rahmadi. 2009. Hukum Kewarisan Islam, Bandung: Mandar Maju

Van Mourik, M.J.A. 1993. Studi Kasus Hukum Waris, Bandung: Eresco

Vollmar, H.F.A. 1996. Pengantar Studi Hukum Perdata. Jilid I. Cetakan 4. Jakarta: Raja Grafindo Persada

\section{Internet:}

"Bolehkah para ahli waris tidak mengindahkan surat wasiat ?," http://m.hukumonline.com/klinik/detail/lt56a9bd466a9a3/bolehkahparaah liwaris-tidak-mengindahkan-surat-wasiat, diakses pada 3 Januari 2017

Dahwal, Sirman, "Abstraksi, Beberapa masalah hukum tentang wasiat," Repository.unib.ac.id/486/1/4-judul tentang wasiat.pdf, diakses pada 10 Januari 2017

\section{Jurnal:}

Abubakar, Fatum, "Pembaruan Hukum Keluarga:Wasiat Untuk Ahli Waris (Studi Komparatif Tunisian, Syiria, Mesir, Dan Indonesia," Jurnal Studia Islamika, Hunafa, Vol. 8 No. 2 Desember, 2011

Manan I. Abdul, "Beberapa Masalah Hukum Tentang Wasiat dan Permasalahannya Dalam Konteks Kewenangan Peradilan Agama,” Mimbar Hukum Aktualisasi Hukum Islam, Edisi IX No. 38 Tahun 1998 
Shofa, Noor, "Jangkauan kewenangan mengadili Pengadilan Agama Dalam Perkara Wasiat,” Mimbar Hukum, Edisi IX No. 38, Juli-Agustus 1998

Tiaraningtyas, RR. Putrie, “Akibat Hukum Wasiat yang Berisi Penundukan Diri Pewasiat Muslim Terhadap Hukum Pewarisan Perdata Bilamana Sebagian Ahli Waris Muslim Mempertentangkan Pilihan Hukum Waris,” Jurnal Fakultas Hukum, Malang: Magister Kenotariatan Universitas Brawijawa

Wijaya M, “Tinjauan Hukum Surat Wasiat Menurut Hukum Perdata,” Jurnal Ilmu Hukum Legal Opinion, Edisi 5 Volume 2, Tahun 2014

\section{Peraturan Perundang-Undangan:}

Instruksi Presiden No. 1 Tahun 1991

Kitab Undang-Undang Hukum Perdata 